\title{
CHALLENGES OF RURAL SMES IN ANKARA, TURKEY
}

\author{
COSKUN SEREFOGLU \& EMINE GOKKAYA \\ Ankara Development Agency, Business Development and Strategy Unit, Turkey
}

\begin{abstract}
Every year, rural areas are experiencing dramatic demographic loss due to the added value they cannot create and a lack of integration with the industry and services sector established in urban areas. Ankara is one of the most prominent regions of Turkey in terms of advanced technology and per capita regional added value. However, the same success was not achieved in the peripheral districts of Ankara. The aim of this study is to determine the current situation of small and medium-sized enterprises (SMEs) in rural areas that are involved in the production and operation and to identify areas for intervention by identifying the challenges they encounter. In-depth interviews were conducted in the study with business founders and inheritors ( $78 \%$ and $22 \%$ respectively). As a result of the study, $93 \%$ of rural SMEs consider that businesses operating in rural areas have serious problems. The biggest obstacle in front of entrepreneurship was found finance, followed by technical staffing and administrative and legal obstacles. In order to get over these obstacles, what is most needed to be addressed is finance, machine-equipment support, marketing and promotional support. One of the most important components that will lead to added value increase in rural areas is export. $82 \%$ of the companies that participated in the survey stated that they do not export. Therefore, it is necessary to develop export-oriented industrial production in rural areas. As a result of this study, it has been found that the institutional capacities of rural enterprises are very low, and there is a need for a support mechanism in order to improve that capacity. There is also a need for efforts to accelerate the transfer of technology produced in the urban areas to the agriculture, tourism and service sectors in rural areas.
\end{abstract}

Keywords: rural areas, rural SMEs, agro-based industry, rural tourism, incentives, Ankara.

\section{INTRODUCTION}

In literature, there are two important issues that rural areas face, one of which is a continuous rural depopulation; the other is severe poverty which is resulted from lack of human capital and technology. One common solution to mitigate the negative effects of isolated rural areas is to establish rural industrialization which creates both new employment and increases the gross value added of raw materials. According to the International Fund for Agricultural Development (IFAD [1]), total rural population is the $55 \%$ of total population in the world, and this is estimated over $56 \%$ in the EU (European Commission [2]). The agriculture sector, with increasing population, is not able to absorb labour force in rural areas. The rural areas are thus unable to prevent outgoing migration to urban areas which bring higher incomes and welfare level to the rural people unless it cannot keep up with the technological advances.

The main challenges are indicated as low-income levels, difficulty to access to social/public services (health, education and transport), low level of skills, knowledge and entrepreneurship and innovation (European Commission [2]). This is also in line with the view of Schmitz [3]. He describes the major difficulties of small local enterprises as access to technology, raw materials, credit or government discrimination. Terluin and Post [4] suggested that increasing competition in urban areas might put a strong pressure on rural areas to reorganize their economy by encouraging continuous innovation and improving social and human capital. This contrasts with the view held by Serefoglu and Yalcin [5]. They hold a view that the rural parts of Ankara are lagging behind technological development in spite of the fact that Ankara is a leading province for technological progress 
in Turkey. The socio-economic indicators support that many districts located in the periphery cannot find a place in the front line according to the socioeconomic development index raking (SEDI [6]).

This study particularly focuses on small-scaled firms, located in rural parts of Ankara, Turkey. The main objective is to analyse in depth the existing situation of rural firms as well as to observe entrepreneurial spirit of those firms. By doing so, we will explain economic success and failures which might have link with founders and inheritors of firms in respect to entrepreneurship. Inheritors, in this study define the business owners who take over the business from a founder or the business inherited from his/her family. This study shows that more than $90 \%$ of the firms consider that rural firms have severe problems. The financial problem is indicated as the biggest obstacle by the respondents, followed by the administrative and legal barriers and difficulty in finding technical staff in rural areas. More than $50 \%$ of the respondents consider that the firms were not aware of reaching financial instruments. On the other side, developing a new product is quite important for export and market demands. In addition, $43 \%$ of the firms say that they do not intend to develop a new product by indicating the difficulty in having staff well equipped.

This paper will provide insight into the existing challenges of rural industries and rural entrepreneurships with a case study from rural Ankara of Turkey. It rests on five main parts. The second part focuses on research methodology after giving introduction in the first part. A brief description of rural areas and rural SMEs of rural Ankara are given in the third part. The fourth part provides findings. The paper is summed up with a short conclusion in the last section.

\section{MATERIALS AND METHODS}

\subsection{Determining sample size and data generation}

Ankara has 16 districts which are located in the periphery. Four districts (Beypazari, Polatli, Haymana, and Cubuk); two of which are from north and south part of Ankara and two from west and east were chosen as pilot districts according to the clustering method. In-depth interviews were made face to face with the firms, with the help of chambers of commerce of each district because the firms would not hesitate to attend interviews.

The number of interviewed firms was calculated according to the simple random sampling. In this method, all individuals have the same chance with the same probability to enter sample according to Kalton [7].

The sample size is defined by considering the current Turkish population and calculated according to the formula provided by Fink [8]:

$$
\mathrm{n}=\frac{N}{\left(1+N * p^{2}\right)}
$$

where $\mathrm{n}$ is the sample size determined, $\mathrm{N}$ is the population size, $\mathrm{p}$ is level of precision. The sample size has been found 50 at $90 \%$ confidence level and $10 \%$ margin of error. But 46 samples were left after 4 firms rejected to attend to the survey. So, response rate was more than $90 \%$.

The sample size is shown in Fig. 1. The survey was realized by three people in between December 2015 and March 2016. The data was processed in Stata/IC.12.0.

The majority of the firms deal with agriculture and agro-based industries with over $60 \%$ as indicated in Table 1 and sectorial breakdown of the respondents can be found in Table 2 . 


\subsection{SMEs definition in the sample}

According to OECD Glossary of Statistical Terms [9] the new definition came into force on 1 January 2005 applying to all Community acts and funding programmes in the European Union, provides for an increase in the financial ceilings and classifies medium-sized enterprises with 50-249 employees and small enterprises with 10-49 employees, and micro firms with less than 10 employees. To understand better we added working by myself to options. In our sample, rural medium-sized enterprises as shown in table 3 composes $6.5 \%$ of rural SMEs. Most of them are micro enterprises with 2-9 workers and compose $54.3 \%$. It is followed by small enterprises with $30.4 \%$ and enterprises composed only by founder are $8.7 \%$.

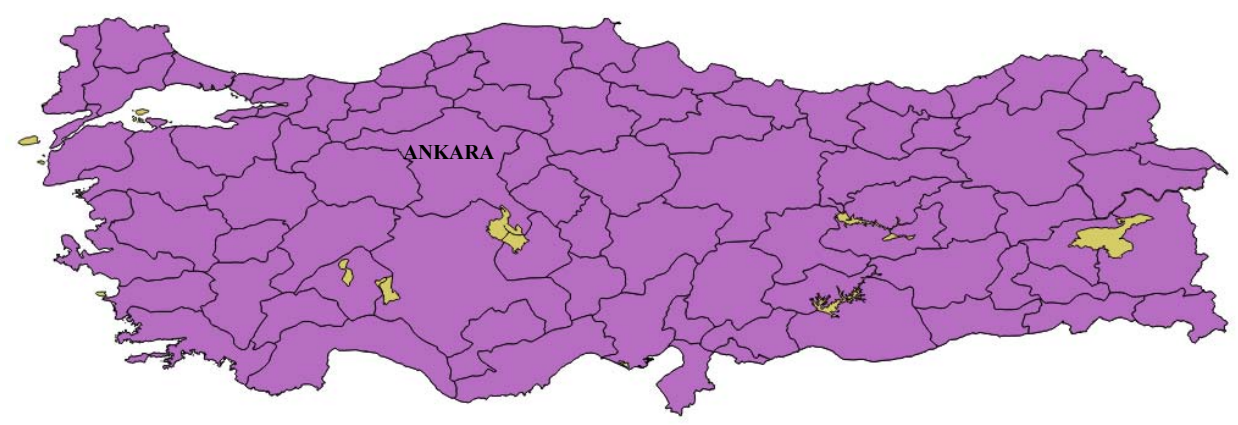

Figure 1: Ankara province on Turkish map.

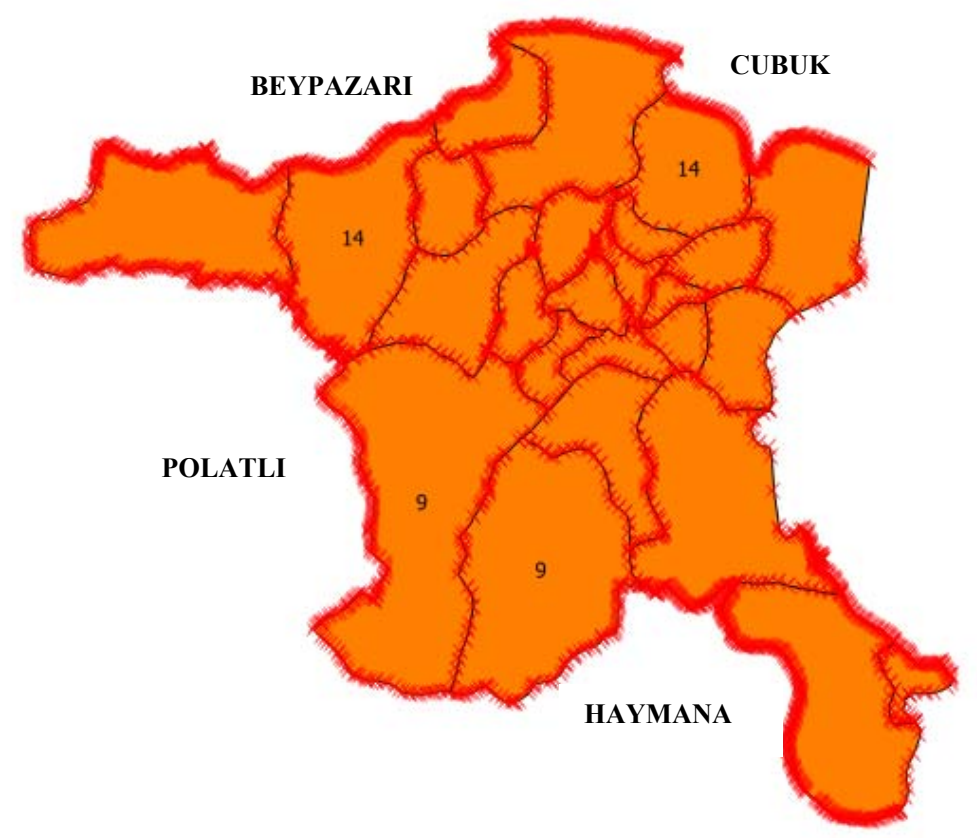

Figure 2: Distribution of the survey on Ankara city map. 
Table 1: The number of surveys made in districts of Ankara.

\begin{tabular}{|l|l|l|l|l|}
\hline District & $\begin{array}{l}\text { The number of } \\
\text { interviews }\end{array}$ & $\begin{array}{l}\text { Realized } \\
\text { interviews }\end{array}$ & $\begin{array}{l}\text { Rejected } \\
\text { interviews }\end{array}$ & $\begin{array}{l}\text { Distance to } \\
\text { city centre }\end{array}$ \\
\hline Beypazari & 14 & 14 & 0 & $103 \mathrm{~km}$ \\
\hline Cubuk & 14 & 14 & 0 & $45 \mathrm{~km}$ \\
\hline Haymana & 9 & 9 & 0 & $75 \mathrm{~km}$ \\
\hline Polatli & 13 & 9 & 4 & $76 \mathrm{~km}$ \\
\hline Total & 50 & 46 & 4 & - \\
\hline
\end{tabular}

Table 2: Sectorial breakdown of the rural firms' survey and the study area.

\begin{tabular}{|l|l|l|}
\hline Sector & $\begin{array}{l}\text { Rural firms } \\
\text { interviewed (\%) }\end{array}$ & $\begin{array}{l}\text { Total in the } \\
\text { study area (\%) }\end{array}$ \\
\hline Wholesaler & 4 & 8.7 \\
\hline $\begin{array}{l}\text { Service (cleaning, transportation, catering, } \\
\text { consultancy) }\end{array}$ & 4 & 8.7 \\
\hline Tourism (hotel, pension, travel) & 5 & 10.9 \\
\hline Agriculture, Animal husbandry, fishery & 28 & 60.9 \\
\hline Forestry, Mining & 1 & 2.2 \\
\hline Construction & 4 & 8.7 \\
\hline Total & 46 & 100 \\
\hline
\end{tabular}

Table 3: \% of workers in our sample.

\begin{tabular}{|l|l|}
\hline Size of enterprises & $\%$ \\
\hline Work by myself & 8.7 \\
\hline $2-9$ workers & 54.3 \\
\hline $10-49$ workers & 30.4 \\
\hline $50-249$ workers & 6.5 \\
\hline
\end{tabular}

\subsection{Survey}

Before surveys were conducted, there were meetings with the head of chamber of commerce in each district so that we could get further and clearer information about the firms and as well as entrepreneurial culture. The questionnaire set were shared with them and improved according to the received feedbacks. Following the meetings, the pre-tests were conducted with five (5) rural firms in order that the perspectives of the firm representatives are truly reflected in the format of questions. The questionnaire form was rearranged with a simple language and in an understandable and clearer way according to negative and positive feedbacks.

The survey mainly comprised four parts. The first part covered the questions to elicit general information about the firms. The grants given by the state organizations were asked in the second part. The third part consisted of specific knowledge about the firms. Personal questions were asked in the last part of the questionnaire form. 


\section{RURAL AREAS AND RURAL SMES IN ANKARA}

Gladwin et al. [10] states that most of the rural areas remain untouched because of the lowincome level and decline in employment. In order to reduce this risk, the author suggests that a perfect information system needs to be developed for the successful entrepreneurship in rural areas. In order to increase productivity of SMSs, productivity-enhancing technical change was suggested as one of the most important instruments by Adelman and Robinson [11] since total factor productivity is quite low in labour-intensive sectors such as agriculture. The growth prospects of most rural small industry basically depend on demand from local agriculture [3].

The share of agriculture in GDP and civilian employment in agriculture accounts for over $20 \%$ according to TURKSTAT [12]. Turkey's rural population accounts for $27.7 \%$ (IPARD [13]). The rural areas, predominantly rural districts in Turkey generally struggle from subsistence farming which does not back up rural industry since development cooperatives and producer unions are not satisfactorily institutionalized. Furthermore, having difficulty in maintaining public infrastructure, covering health care facilities, schools and roads, low density population as well as scattered farms and out-dated business firms, lead to hindering the development of rural areas.

As underlined by OECD [14], the new rural paradigm requires various sectors of rural economies such as rural tourism, manufacturing and ICT sector for the development of rural areas instead of only focusing on agriculture sector. The link between rural and urban areas plays a vital role in transferring technology from urban areas. The more the connection is strong, the more technological development occurs in the rural areas. As approached from this point of view, it can clearly be seen that there is no strong connection between rural and urban Ankara. In spite of the fact that there are a large number of software firms and well-known companies located in urban Ankara, the rural parts of Ankara cannot benefit from this development. Regarding tourism sector, Ankara has a high potential of natural resources, but the tourism activities and the number of visits to the districts are under capacity due to the lack of infrastructure and use of low level technology in the firms. Moreover, the support mechanism shifted from national governments to all levels of government (supra-national, national, regional and local) as well as various local stakeholders (public, private. NGO's) (OECD [14]). In general, it can be said that rural firms in Ankara are too small and quite isolated from technology producing atmosphere of Ankara. Besides that, there is not enough clustering in the rural areas regarding different sectors. The firms therefore have no compatibility. This is argued by Sergenberger and Pyke [15] that the size of firms is not the main problem but the isolation is, so clustering of rural firms plays a vital role for enhancing their capacity for export as well as increase their competitiveness.

\section{FINDINGS}

It is important to know that in the absence of local firms that provide services, rural people may relocate their work site to where services are available. Rural firms that provide services may thus play an important role in keeping rural communities viable (Gladwin et al. [10]). As highlighted by Welsh and White [16], small businesses tend to be clustered in highly fragmented industries such as wholesaling, retailing, services, job-shop manufacturing. As offered to 50 SMEs, returns were received from 46 of them and in-depth interviews were conducted. The participants are classified as founder and inheritor.

Important features of founders and inheritors are summarized in Table 4. At all participants, it comes out that each one in two companies has more than one business but founders are slightly more prone to having more than one business compared to inheritors. 
Table 4: Features and characteristics of founder and inheritor firms.

\begin{tabular}{|l|l|l|l|}
\hline FEATURES (\%) & FOUNDER (\%) & INHERITOR (\%) & AVERAGE (\%) \\
\hline $\begin{array}{l}\text { Have more than one } \\
\text { business }\end{array}$ & 52.78 & 40 & 50 \\
\hline Agriculture industry & 58.33 & 70 & 50 \\
\hline Family business & 91.67 & 70 & 86.96 \\
\hline Aim for partnership & 63.89 & 40 & 58.70 \\
\hline Use of finance & 72.22 & 60 & 69.57 \\
\hline Do export & 22.86 & 0 & 17.78 \\
\hline $\begin{array}{l}\text { Developing a new business } \\
\text { model }\end{array}$ & 80 & 60 & 75.56 \\
\hline Thinking to close business & 8.33 & 0 & 6.52 \\
\hline
\end{tabular}

Even though the reasons for having more than one workplace cannot be explained directly, it is assumed that the desire to benefit indirectly from the grantees and subventions might be a strong reason. The distribution of founders and inheritors shows a similar percentage with the study conducted by Gladwin et al. [10]. In North Florida which reports $12.4 \%$ of founders and $10.5 \%$ of non-founders own more than one business. While the dominant sector is retailing with $42.9 \%$ in North Florida, rural Ankara shows a more agriculture based structure. As foreseen the study showed us that both founders and inheritors prefer to run their business in agriculture, $58.33 \%$ and $70 \%$ respectively.

It is very common to use work power of family in rural areas. Soysal [17] mentions that environment and family structure, literacy and education, socio-economic environment, gender and organizational forms of rural society require all members of family to work together besides lack of financial resources, information and economic development. Our findings prove that both founders and inheritors included their family members to work. $91.67 \%$ of founders and $70 \%$ of inheritors are running family business.

To understand better we asked to participants the reason of founding their business in rural instead of running a business in urban areas. As a matter of course, agriculture is the dominant activity field chosen by our sample, being close to raw materials which are fields and plantations in agro business is $45.7 \%$ among answers. It is followed by being close to family and relatives with $26.1 \%$ and high operating costs in urban areas with $8.7 \%$. IFADILO [18] figures out similar reasons for rural enterprises to be founded in districts because they have limited resources such as labour, skills, and capital, which make it difficult for them to meet the standards required for local, regional, or global markets.

With respect to the working hours of rural SMEs were examined, and it was observed that $34 \%$ of the firms who participated to the interview were working more than 55 hours per week. Interestingly founders with $33.3 \%$ work more than 55 hours, while this ratio is $40 \%$ between inheritors. This difference is similarly found in study of Gladwin et al. [10]. Consecutively 55.6 to 57.1 hour for founders and non-founders. Working 45 to 50 hours is the second common answer with $30.56 \%$ and $20 \%$ between founders and inheritors who participated to our survey. The reason behind the long working hours might occur being engaged in agricultural activities which requires working in field, vineyard, and garden as well as on activities such sales, marketing, accounting for business operations. These factors may be the subject of another research. It is noteworthy that only $13 \%$ (6 firms) of them work less than 40 hours. International labour standards do not give specific guidance on hours of work in agriculture. Instead ILO [19] leaves it to the competent authority in 
each country to determine the appropriate limits, in consultation with the national employers' and workers' organizations.

In the third chapter, which examined the level of entrepreneurship and needs of firms, the respondents were asked about the areas of support most needed for their business. Even it seems that running a business in rural brings many advantages according to participants, $93 \%$ of those firms express that they face certain challenges as well. This ratio is $100 \%$ in Beypazari and Cubuk districts. Access to finance, which means venture capital or equity, profit, bank loan, government grants, founds and any other contribution in kind given by third parties comes out as the first problem. According to surveys, that have been conducted with more than 6,000 companies Regional Investment and Climate Assessment report [20] conducted by the World Bank, it is noted that access to finance is the first problem of $73 \%$ of SMEs in whole Ankara. This is followed by administrative and legal obstacles with 23\% which includes the application procedures of government grants and funds and lack of technical staff with $16 \%$ are the primary problems.

As a secondary problem, high taxation and lack of technical staff, each are representing $17 \%$ of interviewed SMEs. The lack of access to finance besides lack of technical skills and training share the second rank among the top answers in the secondary problem by $15 \%$ of the respondents. $7.5 \%$ of companies reflect that access to support programs is a barrier to the development of SMEs which are active in rural areas. Again, in our survey, $7.5 \%$ of firms stated that they cannot access to EU markets with and this prevents them from developing.

As a third important problem $12 \%$ of firms met with technical skills and training deficiencies. While $9 \%$ of companies mention higher taxation rate as their third important problems, $4.34 \%$ of firms think that administrative and legal obstacles impede their development.

The survey, that rural SMEs were investigated to understand their relation and interaction with public institutions, found out that the number of firms benefiting from state incentives is $50 \% .43 \%$ of these companies benefited from the support provided by the Ministry of Food, Agriculture and Livestock. This is followed by KOSGEB support with $30 \%$. The firms benefited from the support of the Ministry of Science, Industry and Technology are $8 \%$ and the other $4.3 \%$ of SMEs benefited from the incentives provided by the Agricultural and Rural Development Support Agency. The remaining companies were included to the TUBITAK project.

According to data collected in survey, $31 \%$ of the enterprises asked for machineryequipment while $33 \%$ of them raised their need for financial support. Finance pops out as the recurring problem and solution of rural SMEs. SMEs not having the necessary finance are hesitant to undertake entrepreneurial activities and face difficulties in carrying out their current businesses. The reason behind putting finance on the first rank of priorities may be taking the risk of investing though lack of adequate capital or staying behind business goals.

The responses regarding questions interrogating institutional capacities of SMEs figure out a participant character. The percentage of firms who are members of a union or chamber on their business area is $91 \%$. The percentage of firms thinking that it's important to be a member of a union or chamber is $80 \%$. Contrary to participatory character the percentage of firms using counselling services such as business consultant, lawyer and etc. is $47 \%$. The remaining $52 \%$ have not use this type of service or have not need. Firms that do not benefit from counselling services are more likely to get advice from family or friends with $37 \%$ while who apply for public support remains at $29 \%$. $25 \%$ of the 
respondents indicated that they refer to word of mouth while none of the participants stated advising with a chamber, association or a NGO.

Even indicated under developing new products and services, R\&D capacity and the obstacles against it refer to institutional capacity as well. 63\% of SMEs that cannot develop new products stated that they are lagging behind their capacity in this area because of technical staff troubles. An 18\% rate indicates that firms cannot develop new products due to financial problems, while firms corresponding to $9 \%$ have suggested that the necessary management skills are not available. Also, the rest of the companies said that they do not have the necessary infrastructure.

Results showed that in the sector in which it operates, $58 \%$ of the respondents were prone to build new partnerships. Founders showed an affirmative action for partnership with $63.89 \%$ while inheritor ratio was $40 \%$. At overall, $41 \%$ of participators approached with a negative attitude to partnership which is explained as the following. $78 \%$ of noncooperative companies do not think that their partnership will be sustainable for a long time. While $15 \%$ of non-cooperatives do not want to share their commercial and technical secrets the remaining 5\% do not want anyone else to be involved in the management process. In respect to the responses to the partnership idea are examined on a regional basis, participants from Cubuk overwhelmingly responded with $80 \%$. Polatli and Beypazari follow the positive attitude for partnership with $64 \%$ and $53 \%$ consecutively. Haymana is the district which had the most negative aspect for partnership in the business.

As for specific information about company, financial structure is an important indicator for continuity of an enterprise, especially for SMEs. It was reflected by $69.57 \%$ of the participants that financing of their business leans on external resources such as credits, loans, funds and government grants. As it was not the aim of this study to determine what are the percentages, amounts and effects on business, detailed data on allocation of external finance resources was not collected. Briefly $58 \%$ of them use commercial bank loans, $6 \%$ owe to $3^{\text {rd }}$ people and $4 \%$ use commercial banking and leasing. Founders with $72.22 \%$ stand a more vulnerable position due to external finance resources while $60 \%$ of inheritors run their businesses with it.

Private small and medium sized enterprises (SMEs) typically account for more than $95 \%$ of all firms outside the primary agriculture sector, constitute a major source of employment and generate significant domestic and export earnings in the OECD, transition and developing countries. As highlighted by Taş [21], improved SME competitiveness could obviously contribute to economic and social development and poverty reduction. Unfortunately, findings of this study indicate that average of SMEs which export their products or services are only $17.78 \%$. This percentage is a little bit higher between founders with $22.86 \%$. Among the exported countries there are Middle Eastern countries and Turkish Republic as well as Europe and Balkan countries.

Turkoglu and Celikkaya [22] emphasized that the way of achieving economic awareness for SMEs with high added value rest on technological activity. One of the most important technological studies is R\&D activities. As a result, companies and especially SMEs are increasingly dependent on revenues from new products to drive their growth and sometimes sustain their existence [23]. When asked to participants, $57 \%$ at overall state that they develop new product and services. Of those developers, $80 \%$ of founders and $60 \%$ of inheritors mentioned that they develop new products and services.

$75 \%$ of the respondents reflect that there will be an increase in sales revenue if they could develop a new product. With $92 \%$, Beypazari district was at the newest product developer district, while the least new product development occurred in Polatli district with $35 \%$. 
SMEs' role and the potential benefits from sustainable business are gaining more and more importance. Initiatives aiming to increase the interest and uptake of sustainability in SMEs need to be able to engage owner-managers directly with a thorough understanding of their motivations [24]. Among the participants, 93\% of the companies said they would not shut their operation soon. Despite the negativity in growth expectations, asked in survey if they are foreseeing growth in their businesses and earnings in the next two to three years, it is promising that only $6 \%$ of the firms are planning to shut their business. Contrastingly, Gladwin et al. [10] found high failure rate for new, small businesses.

\section{CONCLUSION AND DISCUSSION}

This study aims to analyse the rural SMEs in Ankara. Our focus was to identify the areas which need any kind of support and intervention. The study will serve a kind of support for the policy makers. During the study, in-depth interviews conducted with 50 rural firms in four districts of Ankara. This also helps us in classifying them as founders and inheritors and also their characteristics. As to identify obstacles that SMEs encounters, we figured out finance as the primary source of failure of the rural firms. The second problem comes from co-financing. In order to mitigate the risk of accessing to finance, it is suggested that raising awareness for the financial support programmes and increasing skills of finance management should be given by the responsible authorities since many small firms do not have any assets to guarantee for their commercial relations. For the latter one, one of the most reasonable solutions might be increasing number of the credit guarantee fund or micro finance programmes specific for rural firms.

Finding technical staff well equipped is one of the forthcoming problems indicated by the firms because of the lack of technical schools in the rural areas and attractive job opportunities for young people in urban areas. In order to handle this problem, Package training programmes including various subjects from foundation of a firm until preparation of year-end balance sheet should be systematically organized by related institutions in consultation with academicians working on agriculture, rural tourism, ICT and other fields in rural areas.

The survey proves that the knowledge of export among rural firms is very low due to lack of institutional capacity, lack of technical staff and complicated foreign trade procedures and regulations. Foreign trade also requires owning certain accredit and guarantee. Furthermore, rural firms struggling to access finance resources result in lagging behind competition with peer's due to the imperfect market conditions. All of these reasons force rural population to seek new opportunities in urban areas and lead to a vicious circle in rural areas by putting barriers for rural development. In order to prevent this vicious circle, rural firms should be encouraged to build up clusters regarding similar sectors.

One of the interesting findings coming out in our survey is the question that whether or not the firms which are not economically viable are willing to shut their firms in the short run. The literature supports that the failure rate in new and small firms are quite common. However, interviewed firms indicated that they are not willing to shut their businesses in short run even though they have no expectation to grow or profit in next few years. This is one of the research questions need to be conducted in the future.

\section{ACKNOWLEDGEMENTS}

This research was supported by Ankara Development Agency. We thank Presidents of Chamber of Commerce in Beypazari, Cubuk, Haymana and Polatli who provided insight and expertise that greatly assisted the research, although they may not agree with all of the interpretations/conclusions of this paper. The content of this paper is solely responsibility 
of the authors and does not necessarily represent the official views of Ankara Development Agency.

\section{REFERENCES}

[1] International Fund for Agricultural Development (IFAD). Rural Poverty Report. Overview, International Fund for Agricultural Development, 2011.

[2] European Commission (EC). EU Rural Review, Rural Entrepreneurship, the Magazine from the European Network for Rural Development, (10), 2012.

[3] Schmitz, H., Collective efficiency: Growth path for small-scale industry. The Journal of Development Studies, 31(4), pp. 529-566, 2007.

[4] Terluin, I.J. \& Post, J.H., Economics Dynamics in rural Europe. EU policy for agriculture, food and rural areas, CABI Publishing: Wallingford, Oxon, pp. 309$322,2010$.

[5] Serefoglu, C. \& Yalcin, G., Comparison of development efforts made by different agents in rural Ankara. Journal of Scientific Papers Series - Management, Economic Engineering in Agriculture and Rural Development, 15(2), pp. 341-348, 2015.

[6] SEDI, Ozaslan, M., Dincer, B. \& Ozgur, H., Regional Disparities and Territorial Indicators in Turkey: Socio-Economic Development Index (SEDI). The State Planning Organization Reports, 2004, Online. Accessed on: 10 Mar. 2017.

[7] Kalton, G., Introduction to Survey Sampling. Sage Publications: p. 96, U.S.A, 1983.

[8] Fink, A., The Survey Handbook. 2nd edition. Sage Publications Inc.: London, 2003.

[9] Directorate, OECD Statistics. Small and Medium-Sized Enterprises (SMEs). OECD Glossary of Statistical Terms: 2 Dec. 2005, Web. Accessed on 13 Jan. 2017.

[10] Gladwin, C.H. et al., Rural Entrepreneurship: One Key to Rural Revitalization. American Journal of Agricultural Economics, 1989.

[11] Adelman, I. \& Robinson, S., Income Distribution and Development. Handbook of Development Economics, Chapter 19, pp. 983-985, 1989.

[12] TURKSTAT, Agricultural Statistics, Online. www.tuik.gov.tr. 2015.

[13] IPARD, Instrument for Pre-Accession Assistance Rural Development Programme (2014-2020), The Ministry of Food, Agriculture and Livestock: Ankara, 2015.

[14] OECD, Organisation for Economic Co-operation and Development, the New Rural Paradigm. Policies and Governance, Paris, 2006.

[15] Sergenberger, W. \& Pyke, F., Small firm industrial districts and local economic regeneration. Research and policy issues, in Labour and Society, 16(1), 1991.

[16] Welsh, J.A. \& White, J.F., A Small Business Is Not a Little Big Business, Harvard Business Review, Entrepreneurial Finance, Jul. 1981.

[17] Soysal, A., Kırsal Alanda Kadın Girişimciliği: Türkiye İçin Durum Değerlendirmesi. Eskişehir Osmangazi University. Journal of Economics and Administrative Sciences, 2013, Online. http://iibfdergi.ogu.edu.tr/makaleler/1710109_8-1_N\%C4\%B0SAN \% 202013 Makale 0.pdf. Accessed on: 7 Mar. 2017.

[18] McNab, K.P., International Fund for Agriculture and Rural Development (IFAD). Rep. 6, IFAD-ILO, 2007, Online. www.fao-ilo.org. Accessed on: 10 Apr. 2016.

[19] ILO. C001 - Hours of Work (Industry) Convention, 1919, (1). Article 1; item 3, 2014, Online. Accessed on: 7 Jan. 2017.

[20] Regional Investment Climate Assessment Report For, TR51 II Region Ankara. Local Investment Climate Assessment Project, Online. Ankara: Ministry of Development (2016). http://yatirimortami.kalkinma.gov.tr/. Accessed on: 3 Jan. 2017. 
[21] Taş, N., Promoting SMEs for Development. Proceedings of 2nd OECD Conference of Ministers Responsible for Small and Medium-Sized Enterprises (SMEs), Istanbul, Turkey, 2004, Online. Accessed on: 1 Jan. 2017.

[22] Turkoglu, M. \& Celikkaya, S., R\&D Support for Small and Medium Size Enterprises. Akdeniz University. International Journal of Alanya Faculty of Business, 3(2) pp. 56-71, 2011.

[23] InnoSupport: Supporting Innovations in SME, New product development methods, Online. http://www.innosupport.net/index.php?id=2237, 2005.

[24] Embedding Sustainability in SMEs. www.accaglobal.com. The Association of Chartered Certified Accountants, 2012, Online. Accessed on: 2 Jun. 2015. 